\title{
Examine the Commercialization Research Outcomes in Iran A Structural Equation Model
}

\author{
Mehdi Behboudi (Corresponding author) \\ Lecturer of Marketing, Department of Business Administration \\ School of Management and Accountancy, Qazvin Islamic Azad University, Iran \\ Tel: 98-281-367-0049Ｅ-mail: Behboudi1983@gmail.com \\ Nazanin Jalili \\ School of Management and Accountancy, Department of Public Administration \\ Qazvin Islamic Azad University \\ Nokhbeghan Boulvard, Qazvin, Iran \\ Tel: 98-281-367-0049 E-mail: Nazanin.jalili@gmail.com \\ Morteza Mousakhani \\ School of Management and Accountancy, Department of Public Administration \\ Qazvin Islamic Azad University \\ Nokhbeghan Boulvard, Qazvin, Iran \\ Tel: 98-281-367-0049Ｅ-mail: Mousakhani@qazviniau.ac.ir
}

Received: December 14, 2010 Accepted: January 26, $2011 \quad$ doi:10.5539/ijbm.v6n7p261

\begin{abstract}
The study presents a structural equation model of commercialization. In this study, reviewing the previous studies conducted on commercialization of research outcomes and a content analysis 33 factors affecting commercialization were extracted and categorized in 6 main groups, namely, research-oriented factors, industry-oriented factors, the government, technology parks and growth centers, environment, and commercialization. Then, based on the identified indicators, the conceptual model of commercializing research outcomes was designed and a questionnaire was developed for confirming its factors in Iran, which were confirmed by the experts. Data collected were analyzed by LISREL and the software proposed an appropriate analytical model. The major hypothesis of this study referring to the idea that the 6 constructs mentioned constitute the concept of commercializing research outcomes was significantly confirmed. It was found out that the government is the most influential factor in commercializing research outcomes. Besides, in order to implement the confirmed model a specific methodology was proposed and surveyed. Finally, the Islamic Advertisement Organization was selected as the study field and the results of which are reported.
\end{abstract}

Keywords: Commercialization, Structural equation model, Research outcomes, Technology parks

\section{Introduction}

Economic development, as one of the main goals of governments, has features such as economic growth, production, and increasing wealth endogenously. The paradigm of governments' views toward controlling the economy of countries has been changing from wealth distribution to "wealth production". In some recent decades, commercializing research outcomes has been considered as a way through which wealth can be produced from human and social capitals (Albert Ottawa Report, 2002). Nowadays, technology experts are aware from the fact that the feature of the age of wisdom is using innovation in technology and production which can be achieved by commercializing the latest outcomes of technology gained by innovative ideas (Clarysse \& Moray, 2004).

Innovative ideas can be formed as research projects in universities and research institutes and result in scientific achievements. But directing these achievements toward industry, compensating lack of investment for production, offering them as a product to market, and finally generating economic value from scientific researches is an important step in which governments can play a major role (Kropp and Zolin, 2005). Bridging the gap between university researches and innovators of industry is the mission followed by the governments through establishment of growth centers and technology parks so that they can produce economic profit by 
enhancing commercialization of scientific achievements. Commercialization is a rational process, which commences from idea creation and moves toward market and commerce.

The present study, while investigating the models proposed for commercialization process and researched conducted in this area, embarks on finding the answer to following questions: which factors affect the success of commercialization of scientific achievements? What are the most important factors affecting commercialization of research outcomes in Iran?

\section{Commercialization}

Various definitions have been proposed for commercialization; but to put it simply, commercialization is introducing or offering a new product to market (Courtois, 2004). Canadian government defines commercialization as the process through which research outcomes become operational, and ideas and new findings develop within new products. In this respect, services or technologies are achieved that cab sold throughout the world (Nealy, 2004). Nealy (2004) defines commercialization as the process of reducing expenses of developing and selling a new product. Because the more a product is developed in line with customer/industry needs, the easier it is sold (Kotler, 2001).

In other studies (Rosa \& Rose, 2007; OECD, 2005; Vincent, 2005), commercialization has been defined as activities which change knowledge into product. Previous studies show that the process of developing a product involves four stages. The initial stage relates to concept generation and explorations. The second stage is the stage of technical development and design. The third stage deals with prototype construction and the fourth stage involves commercialization of the product (Vincent, 2005). Procedures have been proposed by researchers for successful commercialization of a product including orientation of market researches, determination of the target market, preparing the business plan, following potential customers, encouraging potential strategic partners, and following financial resources (Raines, 2005).

\section{Literature Review}

Information Technology Association of Canada argues that commercialization is a complex and risky process and from every 3000 new ideas presented in research and development departments, only 1.7, i.e. 51 ideas, proceed to market out of which only one succeed in the market (Courtois, 2004). For a successful commercialization of an idea, the focus must be on strategies, investment in higher education and university researches, creation of infrastructures for public sector's support from research and development, expanding collaboration between government and universities in training the new generation of researchers, and creation of a strong scientific and technical culture. The role of governmental investment for the success of commercialization has been emphasized in the study of Courtois in 2004. Of course, Caerteling, Halman and Doree (2008) have confirmed this role.

Korpp and Zolin (2005) in a study focusing on the development and commercialization of new scientific and technological findings in global economy, argue that having strong ideas is not enough for success, because creative ideas require operational budget to be commercialized and developed. According to this study, involvement of the government and financing commercialization process is a key role. This study is designed on the basis of a framework offered by Lumpkin \& Dess (1996) which considers environmental factors, company orientations, and organizational factors as influencing commercialization of the product. It introduces government as merely a facilitator (Kropp and Zolin, 2005).

Chen et al (2004) conducted a study aimed at investigation of the research and development policies of Taiwanese government. They argue that establishment of science and technology parks and supporting high tech industries are factors contributing to the success of this country. The results of this study show that the criterion of market potential has the highest weight and technology level and government policy rank next (Chen, et al., 2004). Larson and Murray conducted a similar study (2008) in Mexico and China indicating that establishment of Community Learning Centers (CLCs) leads to acceleration of commercialization process (Larson and Murray, 2008).

On the other hand, enhancement of Small and Medium Size Enterprises (SME) has been identified as an efficient method in economical growth and development of countries like Malaysia, Singapore, Taiwan, Thailand, and South Korea (Abdullah, 1999; Aernoudt, 2004; Buratti \& Penco, 2007). The reason is that there is no strict bureaucracy in SMEs, finding staff is done easily, and these industries enjoy high flexibility for accepting new technologies (Payne, 2002). According to UNCTAD report (2002), over 60 to 70 percent of occupations in developing countries has been created by small and medium size businesses. Also, investigation of the share of income-earning of these agencies in the economy of countries show that countries with higher level of GDP have larger sector of small and medium size agencies in comparison to countries with lower GDP level (Dubey et al, 2005). Besides, Vass (2008) referring to previous studies argues that university research can produce economic and social value only when they are commercialized. This study considers development of a private regional investment market, with emphasis on investment on new regional companies, as the key for success (Vass, 2008). 
Furthermore, the technological innovation development department of North Carolina University conducted a study in 2002 with collaboration of the international RTI institute in order to find the best methods of transferring technology in Wake Forest University. In this study they identified the main factors influencing the success of operationalizing and transferring technology in the university as following: 1. Support of top executive manager, 2. Organizational structure, 3. Sufficient resources, 4. Personnel, 5. Promotion of creativity, 6. Risk taking and risk reducing, and 7. Commercialization strategy process. Additionally, the collective commitment for economic construction which is guided by technology, and resources for commencing the activities such as technology park, risk-taking investor, and a commercialization office related to research and economic activities are required (RTI International, 2002).

According to Sun, Ni, and Leung (2007) in Hong Kong, the factors affecting the success of the programs of growth centers include factors depending on environment, factors depending on the growth center, and factors depending on the personnel of the growth center. This study presents the vital success factors of growth centers and technology parks as the followings: 1. Practical and theoretical commitment of the government to the programs of the growth center, 2. Taking market and product factors into account instead of technology, 3 . Communicating with universities from formal relations to informal ones, 4. Financial support, 5. Support service to the personnel of growth centers who are the main agents of the activities of the center (Sun, Ni, and Leung, 2007).

\subsection{Influential Factors}

As it is seen, many studies have been conducted from different viewpoints for finding an appropriate model of commercializing research outcomes. It cannot be accurately determined which viewpoint is more important than the others are. In this regard, one method of finding a more appropriate answer is investigating the commonalities and criteria emphasized in all views. The aim of the present study is identifying and finding the most important factors affecting commercialization. Thus, a collection of factors affecting commercialization process was identified by reviewing models and studies conducted on commercialization of scientific outcomes. Except commercialization concept itself, the five main factors are 1) Research-oriented factors, 2) Industry-oriented factors, 3) Government, 4) Science and technology parks and growth centers, and 5) The environment (Table 1).

Every indicator and its influence upon commercializing research outcomes are presented as a hypothesis. In this respect, a questionnaire was developed and each indicator was presented as separate hypothesis to test its effect on commercialization trend of research outcomes in Iran. The five hypotheses (major constructs) are as following:

Hypothesis 1. Presence of research-oriented factors is considered as a key for commercializing research outcomes.

Hypothesis 2. Presence of industry-oriented factors is considered as a key for commercializing research outcomes.

Hypothesis 3. The direct presence of the government is considered as a key for commercializing research outcomes.

Hypothesis 4. Establishing and supporting technology parks, growth centers, and knowledge-based enterprises affect commercialization of research outcomes.

Hypothesis 5. Coordinating environmental factors with research subjects and functions of industry is a key factor in commercializing research outcomes.

\subsection{Causal Model}

According to the literature and hypotheses formed, a theoretical causal model of commercializing research outcomes in Iran is proposed which involves five exogenous latent variables (research-oriented factors, industry-oriented factors, the government, technology parks and knowledge-based enterprises, and environment) and an endogenous latent variable (commercialization).

\section{Research Methodology}

Content analysis was utilized in order to identify influential factors. Content analysis is a method confirmed by many studies and is considered as one of theoretical research tools (Kassarjian, 1977; Kolbe \& Burnett, 1991; Okazaki \& Rivas, 2002). The factors then were offered to university experts and industry specialists within the framework of a questionnaire to be investigated. In this study, deductive- inductive method was employed so that the international factors affecting commercialization of research activities are identified on the one hand, and their applicability is investigated in Iran, on the other.

Since the questionnaire developed for this study involved a rather large number of questions and it was likely to face with low response rate in case of using electronic tools, like email, for its administration, the printed questionnaire and interview was utilized for collecting data. The questionnaire was administered in person and in presence of at least one member of the research team to most of the experts. The reason was that there were some new concepts and presenting operational definition in the questionnaire could not answer experts' questions 
by itself. By applying these measures, a high response rate (almost $70 \%$ ) achieved. Data collection process commenced at the beginning of May and finished in the middle of Aug 2010.

\subsection{Participants}

An operational definition of expert is proposed in order to identify academic and industrial experts in the field of commercializing research outcomes. According to this definition, an academic expert is the one who 1) Has an educational - scientific position in university, and 2) Has experience in at least one research - scientific area. Also, an industrial expert is the one who 1) Has at least one university certificate and participates directly in the research and development department of a company, and 2) Works in an industrial research institute. In this regard, all members of research centers in Qazvin province are involved in this study. Research centers of this province include the Management Research Center of Qazvin Azad University, the Industrial Research Center of Alborz Industrial Estate, Jahad-e-Daneshgahi, and some intra-university centers. In sum, the number of individuals qualified as experts in this study was 163 all of whom were considered as the participants of this study.

Then, a Likert scale questionnaire was developed to integrate the views of experts in academic specialized criteria and those of the industrial experts in industry-oriented section. From among the participants, 150 individuals were available and the questionnaire was administered to them. In sum, 104 questionnaires were completed and returned. Also, an interview was conducted with the experts about some criteria about which a limited literature was available. For instance, about establishment of applied journals, interview was utilized in addition to the questionnaire.

4.2 Data analysis

The structural equation modeling (SEM) approach was utilized for testing the hypotheses of this study. LISREL 8.53 was used in this regard.

\section{Result}

\subsection{Measurement Model}

The main statistics (mean, standard deviation, and confirmatory factor loadings) for all variables are presented in Table 2. Validation of research instrument was performed by confirmatory factor analysis (CFA) of LISREL measurement model. In order for a feature to be considered as valid, it must have at least 0.6 factor loading with its related construct (Nunnally, 1978). All questions or features obtained this criterion in measurement. Only three features of researchers' flexibility with factor loading of 0.55 , applied journals $(0.56)$, and customers' flexibility (0.58) did not meet this criterion. However, considering the fact that marginal significance is 0.55 (Cho \& Cheon, 2004), these three features were regarded as the confirmed P-Values and were kept in the model. Figure 1, shows the output model of LISREL and confirmatory factors loadings of each factor.

The feature of Beneficial Idea Generation with factor loading of 0.94 has the highest correlation with the construct of "research-oriented factors" in comparison to other indicators, i.e. targeting (0.88), Proficient Scholars (0.86), Feasibility (0.71), modeling (0.66), and researchers' flexibility $(0.55)$. In "industry-oriented factors" construct, the feature financing with factor loading of $(0.91)$ has the highest effect compared to features of customer-oriented (0.87), managers' flexibility $(0.65)$, and technical opportunities $(0.61)$. In the construct "technology parks and knowledge-based companies", the marketing feature with factor loading of (0.89) is highly correlated with the construct in comparison to other features, i.e. expanding research culture (0.79), financing (0.66), creation of competitive advantage (0.62), market technique (0.61), and applied journals $(0.56)$. In the construct "the government" the feature of market creation with factor loading of (0.96) has the highest correlation with this construct compared to the features of financing (0.92), creation of national innovation system (0.88), and establishment of technology parks (0.71). In the construct "environment or environmental factors" the informative system feature with factor loading of $(0.87)$ in comparison to other features, namely, venture investor (0.85), market potential (0.69), economic situation (0.65), and customers' flexibility $(0.58)$, has the highest correlation with the construct of environment. Finally, in the construct "commercialization", the feature of economic development with factor loading of (0.92) has the highest correlation with the construct relative to features of wealth creation (0.87), and attraction of new investors (0.71).

\subsection{Structural Equation Model}

The first step in testing the hypothetical model of the research is estimating model fit (Fig. 1). In this study $X^{2}$ test was employed to find out that the model is fit with the data but does not yield a very good value. The reason is that $X^{2}$ test is very sensitive to the number of the sample and does not yield a good result in structural test most of the times (Cho \& Cheon, 2004). Thus, Bentler \& Bonnet (1980) suggested a $X^{2} /$ degrees of freedom ratio for testing model fitness. In this regard, the number measured was $2.4 ;\left(K^{2}=874.6, \mathrm{df}=369\right)$. As it is shown in Fig. 1, the Normed Fit Index (NFI) was 0.89, the Comparative Fit Index (CFI) was 0.91, and the Root Mean Square Residual (RMSR) was 0.06 . Finally, on the basis of these measurements, it was concluded that the model is a satisfactory one. 


\subsection{Causal Model Analysis}

The second step in testing the model is testing the hypotheses using path significance analysis for each constructs of the research model and variance analysis $\left(\mathrm{R}^{2}\right)$ for each path (the path coefficient and path significance are indicated in Fig. 1 and Table 3). As it was predicted, all five constructs introduced (Hypothesis 1 to 5) have significant effect on commercialization $(\mathrm{p}<0.05)$. In this study, the construct of government with the path coefficient of 0.52 was recognized as the most influential factor compared to other constructs, namely, industry-oriented factors (0.44), research-oriented factors (0.37), establishment of parks (0.19), and environment (0.14). At the end, as it was hypothesized, it was found out that the five constructs (research-oriented factors, industry-oriented factors, technology parks and knowledge-based companies, the government, and environment) constitute the concept of commercialization of research outcomes.

\section{Implementing the Factors}

In order to specify the relationship among the main factors found and their effect on commercialization process in Iran, it was tried to place the main factors identified, i.e. research-oriented factors, industry-oriented factors, technology parks and knowledge-based companies, the government, and environment within the framework of an experiment for objective investigation. From the viewpoint of most international and national experts, the government is a very important factor which plays a crucial role among other factors. Indeed, if this factor is removed from the process of commercialization, this process will face serious problems. Besides, it was identified as the main concern of most national experts in their interviews, because researchers design and develop a research with great efforts and high self-motivation while their achievements neither have a sponsor for employing these outcomes, nor they produce an income source for the researcher.

On the other hand, economic development, as the main user of this process, does not practically enjoy its profits. The review of the literature shows that the main problem of many previous studies is lack of clarity of the role of the government and no clear solution is seen in these studies about the way government's role is played (Sun, Ni, Leung, 2007; Abdullah, 1999; Kropp \& Zalin, 2005; Larson \& Murray, 2008). In other words, almost none of the previous studies have offered a clear strategy showing how it is possible to involve the government in commercialization process. The focus of the present study is on proposing and launching a solution that indicates how the government can be directly involved in commercialization process.

It must be considered that the concept of government is a very broad one. The first step to be taken is to specify what sector of the government must be present in commercialization process. In this respect, by the investigations performed in the research society of Iran, it is found out that in addition to university authorities, two companies of Roz Net and Tebyan issue license for institutes desiring to use digital library. Possessing a digital library is considered as a basic merit among research institutes because it is very expensive and most research institutes in Iran can afford for it.

In this regard, there are two main problems; one of them is the government and the way of its presence and the other is a strong technology park. One suggestion is integrating these two factors and using their strengths jointly. Thus, in order to create the space for government's presence in the process, the research institute of one governmental organization must be selected and developed as a technology park rather that selecting a technology park and encouraging the government to attend. If the institute is located in an appropriate environment, a synergic cooperation will be created among all factors.

\subsection{Selecting the Study Case}

In order to pilot the conceptual model of the study, Qazvin and the electronic library of Islamic Advertisement Organization were selected as the case of study. Qazvin was selected from two viewpoints. First, from the perspective of research-oriented factors because according to the reports; Qazvin province and Qazvin having more than 190000 university students, has the highest rank among other provinces regarding the number of university students (bachelor degree, masters degree, and $\mathrm{PhD}$ ) (Msrt.ir, 2009). Second; from the viewpoint of industry-oriented factors; according to the report of Ministry of Mines and Industries, after Tehran and Isfahan, Qazvin is considered as the third industrial pole of Iran (Mim.gov.ir, 2009).

Hence, Qazvin possesses researchers and the ground for training specialist's researchers on the one hand, and the potential demands for utilizing research appropriate an in line with the needs of industry, on the other. To say it differently, this province is considered as a potential local market for launching the results and findings of the researches (Rothwell \& Zegveld, 1985; Chen, et al., 2004; Sun, Ni, \& Leung, 2007). In this respect, it has the two features of an appropriate environment.

There are several important reasons for selecting the electronic library of Islamic Advertisement. First, Islamic Advertisement Organization of Qazvin is one of the three organizations institutions of this city which have electronic library and has access to domestic and international resources through Tebyan Company. Second, this organization is governmental and plays a supervising role in most affairs of the city in one way or another. It plays an active part in all governmental decisions and requires a research capacity for offering research-oriented packages. Third, this library is exactly placed in the central office of this organization and makes it possible for the researchers to use the facilities of the organization such as conference hall. Fourth, geographically speaking, 
this organization is located at the center of the city is not much far from universities and industrial estates. Fifth, Islamic Advertisement Organization has a central office in the center of all provinces and it is possible to generalize the results obtained for Qazvin to other centers. Finally, this organization has research and development, polling, etc. projects every year that outsources them due to lack of specialist Proficient Scholars.

Thus, the main approach was developing the electronic library into a technology park so that both the electronic library is developed and the authority of organization directors is used for promoting research plans. In this way, both the main problem of way of government role is solved and the government becomes the potential customer of using the result of commercializing research outcomes since it is closely involved in that process.

\subsection{Methodology for Application}

In order to launch the model in the study case a methodology was developed based on which a series of systematic steps would be taken. As it is shown in figure 2, a specific pattern is defined for commercializing research outcomes in the technology park of Islamic Advertisement Organization as a governmental organization. The main activity is done in two departments of research and industry. The research department consists of research forces who are mostly professors of the universities of Tehran and Qazvin as well as administrators of scientific-applied journals.

Scientific-applied journal has two main sections. The first sections is devoted to publishing researched conducted within the technology park of Islamic Advertisement Organization, and the second section introduces new research topic by conducting specialized interviews and gathering information from industry experts. In other words, it invites other researchers for cooperation and collects their ideas and plans in this regard. The research department, due to environmental requirements, has four working groups, i.e. management (marketing, governmental, industrial, and insurance), industry, computer, and mechanics working groups. Industry department is composed of two parts. The first part, industry experts, continuously cooperates with the park, and the second part, part time experts, cooperates with the park according to the study being conducted. In this department, needs assessment and Feasibility of the studies are done by direct participation of industry members and an initial draft is prepared. This draft is passed to research department and decision making is defined and developed as a research problem. Then, he proposed research framework is prepared and is offered to related industry for budgeting. After approval, the research process commences.

\section{Discussion}

The aim of this study was finding the factors affecting commercialization of research outcomes. To this aim, a structural model was developed on the basis of content analysis of previous studies. A questionnaire was designed and administered for testing the proposed hypotheses. LISREL software was utilized for analyzing the data. In general, the study contribution puts into five main dimensions. First, this study is the first attempt for developing a comprehensive model for commercializing research outcomes in Iran. Second, the theoretical foundations of this study are based on a content analysis which explores and collects the main features of commercialization. Third, this study not only introduces the most important factors affecting commercialization, but also prioritizes and introduces the most influential indicators of every factor as well. Fourth, this study offers a valid measurement scale for commercializing research outcomes. The main difference between the present study and previous ones is that confirmatory factor analysis and path analysis has been conducted by LISREL and the structural model of commercializing research outcomes is proposed for the first time in this study. Fifth, this is the first study to test commercialization with three features of attracting new investor, wealth production, and economic development (previous studies concentrated only on wealth production).

\subsection{The government}

Government, as the major factor of commercializing research outcomes, must pay special attention to this area. As the results show, creation of national innovation system and creation of market are the features of the construct of government for operationalizing which great attempts must be made. Government can provide the primary motivation for commercializing research outcomes by requiring the executor of projects to employ the research outcomes of ongoing projects. This study reveals that instead of being provided with research findings, the government must attend at all processes of research and commercializing its outcomes. In this way, not only the demand for research outcomes is created, but the requesting buyer (government) itself plays a direct role in developing the services and the research outcome would be completely customized. It is evident that the role of the government as the major factor in commercializing research outcomes is beyond ordering researches. As the results of the study indicate, creation of national innovation system and according to Ramussen (2008), reforms in the national research system must be considered in the working agenda. That is to say, the government must prepare for productive capacities, motivating the demands of other sectors, and creating market throughout the country. Of course, in this study, only one manifestation of the government which can be involved in commercialization process is depicted.

\subsection{Industry-oriented factors}

Financing and customer-oriented are identified as the main features of industry-oriented factors. On the one hand, industry is considered as the market (purchaser) of knowledge-based products, and on the other, researchers are 
known as the suppliers of these products to industry (Vincent, 2005; Raines, 2005). That is to say, industry must be customer-oriented, and at the same time, finance the budget. It was found out in this study that preparing systematic mechanisms for continuous presence of industry owners in commercialization of research outcomes is necessary. In this respect, according to the objective experience gained by this study, it is suggested that facilities are provided so that a multi-dimensional balance is created between industry mangers and industry clinic through continuous presence of industry managers in industry clinic. This interaction causes creation of productive ideas to be in line with the real needs of the industry on the one hand, and makes industry owners provide appropriate finances for productive ideas by truly understanding the needs of the researchers, on the other.

\subsection{Research-oriented factors}

Beneficial idea generation, as the most important feature of this factor, reveals the real value of intellectual capitals. According to most researchers, the commercialization process basically begins with creation of productive idea (Rothwell \& Zegveld, 1985; Andrew \& Sirkin, 2007). This feature is mostly considered by human capitals and researchers so that proper investments are done for preserving and employing these human capitals (Nealy, 2004). Many countries have considered university reforms to support human capitals by commercializing research outcomes (Lehrer \& Asakawa, 2004a; Slaughter \& Leslie, 1997; Zhao, 2004).

\subsection{Technology parks and knowledge-based companies}

Marketing has been recognized as the main indicator of technology parks, growth centers, and knowledge-based companies. This factor has been neglected so far due to lack of correct understanding (Farjadi \& Riahi, 2007). Establishment and development of marketing unit can result in achieving the followings: 1. To promote the research outputs and select the appropriate customer and take the primary actions before the end of research projects; 2 . To identify the real needs of industry and provide the appropriate input $\mathrm{s}$ of technology park system by processing them; 3. Marketing can attract more researchers and industries by advertising the park and knowledge-based companies and create better relations. At present, due to lack of appropriate attention to this part, technology parks face input problem and most their services, such as market technique and industry clinic remain unknown for researchers and industry owners. Also, technology parks must directly cooperate with a research-scientific journal or try to change into a research-scientific journal so that a scientific method governs the whole process, on the one hand, and motivation is created for researchers' participation and conduction research projects in these organizations. One of the main problems of research in the country is researchers' enthusiasm for publishing papers in international journals. Therefore, they try to target the requirements of those journals and develop the range of their research and theoretical framework according to national and local requirements.

\subsection{Environment}

Informative system and risk-taking or venture investor, with minor difference, were identified as the main indicators of the construct environment. Risk-taking investors are called business angles (Samadaghaie, 2003). Risk-taking or venture investor is the feeding source of commercialization engine. Risk-taking investors have played a role in more than two third of new jobs and 95 percent of innovations and establishment of entrepreneurial businesses in that last 25 years (Allen, 1999; Timmons \& Spinelli, 2003; Chen, 2009). However, they face several problems, such as lack of sufficient knowledge about the environment, lack of enough experience about product development, and concern about the return of their capital (Feeser \& Willard, 1990; Shan, 1990; Zahra \& Covin, 1993). Risk-taking investors are the vulnerable part of commercialization (Chen, 2009) and need special attention on the part of the government for facilitating commercialization of research outcomes.

However, the information system, whose main goal is making information accessible and proving easy access to information (Mohammadnejad \& Delangiz, 2006) must be seriously employed for promoting the knowledge of risk-taking investor about the environment and reducing their risks. The main output of comprehensive information system is easy acceptance of products produced and introduced on the basis of innovative ideas.

In general, commercialization of creative ideas and achievements of knowledge-based activities, or in other words changing creativity and human knowledge (intellectual capitals) into product to be sold in the market, is a sustainable solution in production of wealth and encouraging more investors to participate in the profitable activities of these processes. As this study indicates, government can be the stimulator of this process in the first step by participating in all phases of commercialization of researchers' ideas and expect this process to end in wealth production and economic growth of the country in the next step. Particularly, in developing countries where the rate of national saving is lower than the desired level (Todaro, 2009) and the possibility of attracting capital for wealth production and economic development is limited, focus on commercialization of research outcomes which is considered as an endogenous factor of development is very important. Since development is a dynamic social movement and is defined as a continuous advancement of the whole society and social system toward a better life (Todaro, 2009) the necessity of sustainability and continuality of wealth production and economic growth becomes clear. If wealth production relies upon local forces and national researchers and 
industries based on market demands, so that the result of their activities provides the possibility of attracting new investments, the resulting growth would be a sustainable one and lead to development of the country.

In this study, the main bases of commercialization of research outcomes are presented through exploring more than 80 previous studies which can be a good portal for this subject. In this regard, each of the main factors and their indicators can be a future research area. Particularly, two variables of attracting new investors and economic development are new factors added to the process of commercialization and the way they affect and are effected can be investigated in more detail.

\section{References}

Abdullah, M. A. (1999). The Accessibility of the Government-sponsored Support. Programs for Small and Medium-sized Enterprises in Penang. Cities, 16 (2), 83-92.

Aernoudt, R. (2004). Incubators: tool for entrepreneurship? Small Business Economics, 23, 127-135.

Agrawal, M. P., Pratap S., Sunil. K., Mahan S., \& Arun, M. (2005). Benchmarking of technology Park/Incubator: The new Paradigm for SMEs. Institute for Small Business \& Entrepreneurship, National Conference, Nov. 2005.

Aguirre, M. S. (2001). Family, economics and the information society - how are they affecting each other? International Journal of Social Economics, Vol. 28 (3), pp. 225-47.

Aimana, S. Aminullah, E., \& Simamoraa, M. (2007). Commercialization of Public R\&D in Indonesia. A paper presented at National Workshop on 'Sub-national Innovation Systems and Technology Capacity Building Policies to Enhance Competitiveness of SMEs' April 3-4, 2007 Jakarta.

Alaei Tabtabaee, S. A. (2008). Challenges for Forming Technology Market in Iran. Pardis Quarterly Journal of Technology Park, 17 (3).

Albert Ottawa Report. (2002). The Commercialization of University Research. Association of university and colleges of Canada. [Online] Available: www.ovacltd.com/Albert\%20Pecora\%20CV.pdf

Allen K. (1999). Growing and Managing an Entrepreneurial Business. New York: Houghton Mifflin.

Amirahmadi, H., \& Saff, G. (1993). Science Parks: A Critical Assessment. Journal of Planning Literature, 8 (2), 107-123.

Andrew, J., \& Sirkin, H. (2007). Payback: Reaping the Rewards of Innovation. Harvard Business School Press. [Online] Available: http://hbr.org/search/harold+1+sirkin

Angelou Economics. (2006). Research District Land Use and Marketing Plan; Delivered to Tri-Cities Research District. Kuchler, White Paper, Queensland Innovation Council, Australia

Bamdad N., Farjad. G., \& Riahi, P. (2008). Proposal Method in Marketing Management of Technology Parks, Quarterly Journal of Research \& Planning in Higher Education, 14 (3), 69-95. [Online] Available: http://journal.irphe.ir/browse.php?a_code=A-10-1-123\&slc_lang=en\&sid=1\&ftxt=1

Baronchelli, G. (2004). Branding Strategy as a STP's Competitive Advantage. Gianpaolo Baronchelli, Fabio Cassia, Alessandra Cominetti, Roberto Rinaldi, Paola Silli; XXI-IASP World Conference on Science and Technology Parks, Bergamo, (2004).

Beggs, A. (2006). Marketing Research Parks. IASP World Conference, Helsinki, 2006.

Bentler, P. M., \& Bonnet, G. D. (1980). Significance Tests \& Goodness of Fit in the Analysis of Covariance Structure. Psychological Bulletin, (88), 588-606.

Buratti, N., \& Penco, L. (2001). Assisted Technology Transfer to SMEs: Lessons from an Exemplary Case. Technovation, 21 (1), 35-43.

Caerteling, J. S., Halman, J. M., \& Dorée, A.G. (2008). Technology Commercialization in Road Infrastructure: How Government Affects the Variation and Appropriability of Technology. Journal of Product Innovation Management, 25 (2), $143-161$.

Courtois, B. A. (2004). Commercialization. Information Technology Association of Canada, May 2004, p1. [Online] Available: http://www.itac.ca/pdf/04may_issue_commercialization.pdf

Chan K. F., \& Lau, T. (2005). Assessing Technology Incubator Program in the Science Park: the Good, the Bad and the Ugly. Technovation, 25, 1215-1228.

Chen, C. J. (2009). Technology commercialization, incubator and venture capital, and new venture performance, Journal of Business Research, 62 (1), 93-103

Chen, C. J., Chen, H., \& Chin, C. (2004). A Multiple Criteria Evaluation of High-tech Industries for the Science-based Industrial Park in Taiwan. Information \& Management, 41.

Cho, C. H., \& Cheon H. J. (2004). Why Do People Avoid Advertising on the Internet. Journal of Advertising, 33, (4), 89-97.

Clarysse, B., \& Nathalie M. (2004). A Process Study of Entrepreneurial Team Formation: The Case of a Research-based Spin-off. Journal of Business Venturing, 19 (1), 55-79. 
Dodgson, M. (2000). The Management of Technological Innovation: An International and Strategic Approach. Oxford University Press. ISBN 0198775369.

Dosi, G. (1984). Technical change and Industrial Transformation. New York: St. Martins Press.

Dosi, G. (1988). The nature of the innovation process. In: Dosi, G., Freeman, C., Nelson, R., Silverberg, G., Soete, L. (Eds.), Technical Change and Economic Theory. Pinter, London, pp. 221-238.

Dubey, M. P., Agrawal, S., Singh, K. S., \& Manu, M. S. (2005). Benchmarking of technology Park/Incubator: The new Paradigm for SME s, Institute for Small Business\& Entrepreneurship, National Conference, Nov 2005.

Fakoor, b. (2004). Commercialization of Research Outcomes. Quarterly Journal of opportunity, 34 (4).

Farjadi, G., \& Riahi, P. (2007); "Study of Local Market for Iranian Science and Technology Parks"; Quarterly Journal of Research and Planning in Higher Education; 13 (2), 20-48. [Online] Available: http://journal.irphe.ir/article-A-10-1-76-1-en.html

Fecteau, A. (2004). Business Attraction vs. Business Retention"; Alain Fecteau, Jean_Pierre Rodrigue, Roger Poulin; XXI-IASP World Conference on Science and Technology Parks, Bergamo, 2004. [Online] Available: www.carolstream.org/business/.../BusinessAttractionRetention.htm

Feeser H. R., \& Willard, G. E. (1990). Founder Strategy and Performance: a Comparison of High and Low Growth High Tech Firms. Strategy Manage Journal, 11 (2), 87-98.

Fukugawa, N. (2006). Assessing the Impact of Science Parks on Knowledge Interaction in the Regional Innovation System. Working Paper series 19 June 2006, [Online] Available: http://papers.ssrn.com/sol3/papers.cfm?abstract_id=909464

Goldsmith .H. R. (1999). University of Arkansas small Business and Technology Development Center, H. Randall Goldsmith Developed a Conceptual Framework for the Process of Commercializing Advanced Technologies; Website source: Arkansas Economic Acceleration Foundation. [Online] Available: www.aeac.arcapital.com/technology_commercializationCatalogueno.88F0006XIE10StatisticsCanada

Griddings, S. R. (2005). Marketing for Incubator Managers \& Guidelines to Assist their Clients in their Marketing"; Workshop on Science and Technology Parks Market and Planning, Isfahan. Iran, October 2005.

Hammerstedt, R. H., \& Blach. E. L. (2008). Commercialization of Basic Research from within the University \& Return of Value to the Public. Animal Reproduction Science, 105, 158-178.

Jensen, R., \& Thursby, M. (2001). Proofs and prototypes for sale: the tale of university licensing. American Economic Review, 91 (1), 240-259.

Kassarian, H. J. (1977). Content analysis in consumer research. Journal of Consumer Research, 4, June, pp. 8-18.

Klein, T. A., \& Nason, R. W. (2001). Marketing and development: macro-marketing perspectives. in Bloom, P. N. and Gundlach, G.T. (Eds), Handbook of Marketing and Society, Sage, Thousand Oaks, CA.

Kline, S. J., \& Rosenberg, N. (1986). An overview of innovation. In: Landau, R., Rosenberg, N. (Eds.), The Positive Sum Strategy: Harnessing Technology for Economic Growth. National Academy Press, Washington, pp. 275-307.

Kolbe, R. H., \& Burnett, M. S. (1991). Content-Analysis research: an examination of applications with directives for improving research reliability and objectivity. Journal of Consumer Research, 18 (2), 243-50.

Kotler, P. (2001). Marketing Management Millennium Edition. Prentice Hall, Inc. Tenth Edition, Ney Jersey, Unite State of America

Kropp, F., \& Zolin, R. (2005). Technological Entrepreneurship and Small Business Innovation Research Programs. Academy of Marketing Science Review, 7, 1-14. [Online] Available: http://www.amsreview.org/articles/kropp07-2005.pdf

Larson, R. C., \& Murray, M. E. (2007). Distance Learning as a Tool for Poverty Reduction And Economic Development: A Focus on China and Mexico. Journal of Science Education and Technology, 17 (2) 175-196.

Lehrer, M., \& Asakawa, K. (2004a). Pushing scientists into the marketplace: promoting science entrepreneurship. California Management Review, 46 (3), 55-76.

Levit, T. (2001). Innovation for Competitive Advantage, in Innovation: A Blue Print for Surviving and Thriving in an Age of Change. Stephen Shapiro, 2001, pp. 7-30.

Luger, M. (2000). Science and Technology Parks at the Millennium: concept, history, and metrics. In Transforming Ames into a Commercially Viable Research Center, ed. C Wessner, National Academies Press, 2000 .

Luger, M. I., \& Goldstein, H. A. (1991). Technology in the Garden: Research Parks and Regional Economic Development. The University of North Carolina Press, Chapel Hill and London. 
Lumpkin, G. T., \& Dess, G. G. 1996. Enriching the entrepreneurial orientation construct: A reply to Entrepreneurial orientation or pioneer advantage. Academy of Management Review, 21 (3), 605-607.

Metaxas, T., \& Dimitris K. (2004). Medium Sized Cities' Economic Development and Regional Competitiveness: The case of Larissa-Volos Dipole in Thessaly Region on Greece"; $9^{\text {th }}$ Regional Studies Association International Conference, Pisa Conference Center.

Mim.gov.ir. (2009). Ministry report for industrial cities in Iran. [Online] Available: http://www.mim.gov.ir/index.php?name=Search\&action=search\&active_stories=1\&showresult=1

Miraminin, S. R. (2007). Introducing New Technology Development Box, Quarterly Journal of Pardis, 16 (2), [Online] Available: http://www.magiran.com/magtoc.asp?mgID=4595\&Number=21

Mohammad nejad, N., \& Delangiz, S. (2005). Structure, Infrastructure, \& Requirements of Technology in Iran. [Online] Available: http://www.razi.ac.ir

Moshiri, B. (1999). Technology Parks, Organizational Structure, Creativity \& Innovation Development. First Conference on Creativity Identification, TRIZ, \& Engineering \& Managing Innovation in Iran, [Online] Available: http://www.Civilica.com

MSRD. (2001). "Buiding a Commercial Base for Tomorrow's Industries, a Framework for Victoria's Technology Parks"; Ministry for State and Regional Development, Australia, [Online] Available: www.business.vic.gov.au/.../13businessstatement-full.pdf

Msrt.ir. (2009). Report on Student's Situation in Higher Education. [Online] Available: http://www.msrt.ir/moreinfo.aspx?url=http\%3a\%2f\%2fwww.msrt.ir\%2fsites\%2fArzyabi\%2f22\%2

Mullen, M. R., Beller, E., Remsa, J., \& Cooper, D. (2001). The Effects of International Trade on Economic Growth \& Meeting Basic Human Needs. Journal of Global Marketing, 15 (1), 31-55.

Nealy, M. S. (2004). The Budget Plan of Canada page 133. [Online] Available: http://www.scottmcnealy.com Nunnally, J. C. (1978). Psychometric Theory. New York: McGraw Hill.

OECD. (2005). Guidelines for Collecting and Interpreting Innovation Data. Oslo Manual, 3rd edition, Paris, page 49.

Okazaki, S., \& Rivas, J. A. (2002). A content analysis of multinationals' Web communication strategies: Cross-cultural research framework pre-testing. Internet Research; Electronic Network and Applications Policy, $12(5), 380-390$.

Oshani, N. A. (2004). Determining the Role of Science and Technology Parks in Different Models of Technology Development. Research Paper; Isfahan Science and Research Town, Iran.

Padova, Al. (2005). Federal Commercialization in Canada. Parliamentary Information and Research Service, Economics Division. [Online] Available: www.2.parl.gc.ca/Content/LOP/ResearchPublications/prb0545-e.pdf

Payne, J. E. (2002). E-Commerce Readiness for SMEs in Developing Countries: A Guide for Development Professional. Produced by: Learn Link Academy for Educational Development, U.S. Agency for International Development. [Online] Available: http://www.learnlink.aed.org/Publications/Concept/ecommerce_readiness.pdf Raines, L. (2006). SBIR Commercialization success factors," TechNET WV.Small business Development, [Online] Available: http://63.65.212.51/smallbusiness/.../TechNetWestVirginiaOctober2006

Rasmussen, E. (2008). Government instruments to support the commercialization of university research: Lessons from Canada. Technovation, 28, 506-517.

Rosa, J., \& Rose, A. (2007). Report on interviews on the commercialization of innovation. A working paper, Science, Innovation and Electronic Information Division (SIEID).

Rothwell, R. Y., \& Zegveld, W. (1985). Reindustrialization and Technology. Longman, Essex, G. B.

RTI International. (2002). Key Factors in the Successful Evolution of Technology Transfer At Wake Forest University "Technology Assessment and Commercialization. [Online] Available: www.wfubmc.edu/WorkArea/DownloadAsset.aspx?id=28699

Rubini, D. (2002). A Critical Analysis of Science and Technology Parks: Learning from the Italian Experience; Thesis for the Degree of Master of Science in Engineering Policy and Technology Management.

Salari A. (2003). Market Technique, the Base of Technology Exchanges. Pardis Park, Atena Publication, P. 38-39.

Samadaghaie, J. (2004). Venture capitalist industry is the lost loop of national innovation system. The first national congress on venture capitalist, Tehran, Iran.

Sancin, M., \& Leonardo M. (2004). The $6^{\text {th }}$ P"; XXI-IASP World Conference on Science and Technology Parks. Bergamo, 2004.

Shan, W. (1990). An empirical analysis of organizational strategies by entrepreneurial high-technology firms. Strategy Manage Journal, 11 (2), 129-39. 
Slaughter, S., \& Leslie, L. L. (1997). Academic Capitalism: Politics, Policies, and the Entrepreneurial University. Johns Hopkins University Press, Baltimore.

Sun, H., Ni, W., \& Leung, J. (2007). Critical Success Factors for Technological Incubation: Case Study of Hong Kong Science and Technology Parks. International Journal of management, 24 (2), 346-363.

Timmons J. A., \& Spinelli S. (2003). New venture creation: entrepreneurship for the $21^{\text {st }}$ Century. Sixth edition, McGraw Hill, Boston.

Todaro, P. M., \& Smith, C. S. (2009). Economic Development. 8th Edition. Addison Wesley, London, England. UNCTAD.com. (2002). The E-Commerce and Development Report 2002. United Nations Conference on Trade Development, [Online] Available: http://www.unctad.org/templates/webflyer.asp?docid=2923\&intItemID=2642\&lang=1\&mod UNIDO. (2005). Advising and Monitoring the Planning of a Technology Park: Guidelines for an ICT park in Iran, United Nations Industrial Development Organization; Ordered by MAGFA, Iran.

Valdani, E., \& Ankarani, F. (2006). Marketing Places: A Resource based Approach and Empirical Evidence from the European Experience. Universita Commerciale, Luigi Bocconi, Milan, Italia; [Online] Available: $\mathrm{http}: / / \mathrm{www} . u n i b o c c o n i . i t / \mathrm{wps} / \mathrm{wcm} / \mathrm{connect} /$ SitoPubblico_IT/Albero+di+navigazione/Home/?lang=it

Vass, T. E. (2008). Successful Tech Transfer=Market Commercialization, Private Capital Market Working Paper. Retrieved November 2008 [Online] Available: http://www.oa.upm.es/5067/2/INVE_MEM_2009_63739.pdf Vincent, L. H. (2005). Marketing Strategy Formulation in the Commercialization of New Technologies. Georgia Institute of Technology, Collage of Management, PhD Thesis.

Wharton. (2003). An Analytical Framework of Science Parks and Technology Districts with an Application to Singapore. Journal of Business Venturing, Special Issue on Science Parks and Incubators, September 2003.

Yahya. M, Kasem, Feinstein, Leo, G. (1990). Success Factors in Applied R\&D Strategies in The Microelectronics Industry, A Customer - centered Approach. IEEE International Engineering Management Conference.

Zahra S. A., \& Covin J. G. (1993). Business strategy, technology policy, and company performance. Strategy Manage Journal, 14 (6), 451-78.

Zhang, Yuehua. (2005). The Science Park Phenomenon: Development, Evolution and Typology. Int. J. Entrepreneurship and Innovation Management, Vol. 5, No. 1/2, pp. 138-154.

Zhao, F. (2004). Commercialization of research: a case study of Australian universities. Higher Education Research and Development, 23 (2), 223-236. 
Table 1. Content Analysis for Identifying Factors Affecting Commercialization of Scientific Achievements

\begin{tabular}{|c|c|}
\hline \multicolumn{2}{|c|}{ 1. Research Oriented Factors } \\
\hline $\begin{array}{l}\text { Beneficial Idea } \\
\text { Generation } \\
\text { Scholars' Flexibility } \\
\text { Targeting } \\
\text { Feasibility } \\
\text { Modeling }\end{array}$ & $\begin{array}{l}\text { (Goldsmith .H. Randall, 1999; RTI International, 2002; Wharton, 2003; Su, Ni, and } \\
\text { Leung, 2007; Rosa and Rose, 2007; Larson \& Murray, 2008) } \\
\text { (Rothwell \& Zegveld, 1985; Wharton, 2003; Vincent, Leslie, \& Harrise, 2005; Andrew } \\
\text { \& Sirkin, 2007; Rosa and Rsoe, 2007, RTI International, 2002) } \\
\text { (Yahya \& Feinstein, 1990; Rosa and Rsoe, 2007) } \\
\text { (Goldsmith, 1999, ) } \\
\text { (Goldsmith, 1999, RTI International, 2002 ) } \\
\text { (Rothwell \& Zegveld, 1985; Goldsmith, 1999; Rosa and Rsoe, 2007; Andrew \& } \\
\text { Sirkin, 2007, Raines, 2006) }\end{array}$ \\
\hline \multicolumn{2}{|c|}{ 2. Industry-Oriented Factors } \\
\hline $\begin{array}{l}\text { Financing } \\
\text { Customer-Oriented } \\
\text { Manager' Flexibility } \\
\text { Technical Opportunity }\end{array}$ & $\begin{array}{l}\text { (Padova, 2005; Rosa \& Rsoe, 2007, RTI International, 2002 ) } \\
\text { (Yahya \& Feinstein, 1990; Fecteau, 2004; Baronchelli, 2004) } \\
\text { (RTI International, 2002; Vincent, 2005, Kropp, and Zolin, 2005, Payne, 2002) } \\
\text { (Rothwell and Zegreld, 1985) }\end{array}$ \\
\hline \multicolumn{2}{|l|}{ 3. Government } \\
\hline $\begin{array}{l}\text { Developing National } \\
\text { Innovation System } \\
\text { Establishing Tech Parks }\end{array}$ & $\begin{array}{l}\text { (Fakoor, 2004; Mohammadnejad \& Delangiz, 2006; Agrawal \& Mahan, 2005; Aimana, } \\
\text { \& Simamora, 2007; Caerteling, Halman, Dorée ,2008, Nealy, 2004, Su, Ni \& Leung, } \\
\text { 2007) } \\
\text { (Kline and Rosebberg, 1986; Dosi et al., 1988; Mohammadnejad \& Delangiz, 2005; } \\
\text { Levit, 2001, Aimani, \& Simamora, 2007) } \\
\text { (Luger, 2000; Rubini, 2002; Su, Ni, Leung, 2007, Nealy, 2004, Larson and Murray, } \\
\text { 2008, Aimana, \& Simamora, 2007) } \\
\text { (Caerteling, Halman, Dorée, 2008, Aimana, \& Simamora, 2007) }\end{array}$ \\
\hline \multicolumn{2}{|c|}{ 4. Factors Related To Establishing Technology Parks And Growth Center } \\
\hline $\begin{array}{l}\text { Expanding Research } \\
\text { Culture } \\
\text { Tech Market } \\
\text { Financing } \\
\text { Applied Journals } \\
\text { Creating competitive } \\
\text { advantage }\end{array}$ & $\begin{array}{l}\text { (Luger and Goldstein, 1991; Amirahmadi, \& Saff, 1993; MSRD, 2002; Baronchelli et } \\
\text { al., 2004; Chan \& Lau, 2005; Bamdad, Farjadi, \& Riahi, 2007; Farjadi \& Riahi, 2007) } \\
\text { Bamdad, Farjadi, \& Riahi, 1999; Baronchelli, 2004; Fecteau, 2004; Najaf Oshani, 2004; } \\
\text { UNIDO, 2005; Griddings, 2005; Fukugawa, 2006; Angelou Economics, 2006; RTI } \\
\text { International, 2002, Su, Ni, \& Leung, } 2007 \\
\text { (Moshiri, 1999; Beggs, 2006) } \\
\\
\text { Salari, 2003; Alaei Tabatabaee, 2008, RTI International, 2002 ) } \\
\text { (Moshiri, 1999; Sedigh, 2002, RTI International, 2002) } \\
\text { (Beggs, 2006) } \\
\text { (Dosi, 1984; Moshiri, 1999; Lever and Turok, 1999; Dodgson, 2000; Metaxas \& } \\
\text { Kallioras, 2004) }\end{array}$ \\
\hline \multicolumn{2}{|l|}{ 5. Environment } \\
\hline $\begin{array}{l}\text { informative System } \\
\text { Venture Capital } \\
\text { Market Pull } \\
\text { Customer Flexibility } \\
\text { Economy Condition }\end{array}$ & $\begin{array}{l}\text { (Larson, and Murray, 2008, Aiman, Aminullah, Simamora,2007) } \\
\text { (Miramini, 2008, Vass, 2008, RTI International, 2002 } \\
\text { Roth well \& Zegveld, 1985, Chen, Huang, Chen, 2004, Leung, Su, Ni } 2007 \\
\text { (Valdani \& Ankarani, 2006; Rosa \& Rase, 2007) } \\
\text { (Rosa \& Rase, 2007, Kropp, and Zolin, 2005) }\end{array}$ \\
\hline \multicolumn{2}{|l|}{ 6. Commercialization } \\
\hline $\begin{array}{l}\text { Attracting investment } \\
\text { Creating wealth } \\
\text { Economic development }\end{array}$ & $\begin{array}{l}\text { (Goldsmith, 1999, ) } \\
\text { (Albert Ottava Report, 2002; Kropp, and Zolin, 2005) } \\
\text { (Abdullah, 1999; Albert Ottava Report, 2002; Rasmussen, 2008; Lehrer \& Asakawa, } \\
\text { 2004a; Slaughter \& Leslie, 1997; Zhao, 2004). }\end{array}$ \\
\hline
\end{tabular}


Table 2. The key Statistics

\begin{tabular}{|c|c|c|c|c|c|c|}
\hline Latent variables & Observer variables of items & $\mathbf{N}$ & Mean & SD & $\begin{array}{l}\text { Confirmatory } \\
\text { factor loadings }\end{array}$ & Cronbach \\
\hline \multirow[t]{6}{*}{ Research Oriented Factors } & Proficient Scholars & 103 & 4.2 & 0.34 & 0.86 & \multirow{6}{*}{0.78} \\
\hline & Beneficial Idea Generation & 104 & 4.5 & 0.57 & 0.94 & \\
\hline & Scholars’ Flexibility & 103 & 3.6 & 0.4 & 0.55 & \\
\hline & Targeting & 102 & 4.2 & 0.34 & 0.88 & \\
\hline & Feasibility & 102 & 3.9 & 0.6 & 0.71 & \\
\hline & Modeling & 102 & 3.8 & 0.34 & 0.66 & \\
\hline \multirow[t]{4}{*}{ Industry-Oriented Factors } & Financing & 100 & 4.4 & 0.45 & 0.91 & \multirow[t]{4}{*}{0.73} \\
\hline & Customer-Oriented & 101 & 4.2 & 0.5 & 0.87 & \\
\hline & Managers' Flexibility & 102 & 3.8 & 0.23 & 0.65 & \\
\hline & Technical Opportunities & 100 & 3.7 & 0.3 & 0.61 & \\
\hline Technology Parks And & Marketing & 102 & 4.3 & 0.25 & 0.89 & \multirow[t]{7}{*}{0.76} \\
\hline \multirow{6}{*}{$\begin{array}{l}\text { Knowledge-based } \\
\text { companies }\end{array}$} & Interaction & 102 & 4.1 & 0.24 & 0.71 & \\
\hline & Expanding Research Culture & 103 & 4.1 & 0.8 & 0.79 & \\
\hline & Tech Market & 103 & 3.9 & 0.6 & 0.61 & \\
\hline & Financing & 102 & 4.2 & 0.5 & 0.66 & \\
\hline & Establishing Applied Journals & 102 & 3.5 & 0.33 & 0.56 & \\
\hline & Creating competitive advantage & 102 & 3.9 & 0.46 & 0.62 & \\
\hline \multirow[t]{4}{*}{ Government } & Budget Financing & 103 & 4.5 & 0.27 & 0.92 & \multirow[t]{4}{*}{0.81} \\
\hline & National Innovation System & 102 & 4.2 & 0.21 & 0.84 & \\
\hline & Establishing Tech Parks & 101 & 4.1 & 0.43 & 0.71 & \\
\hline & Market Creation & 101 & 4.3 & 0.17 & 0.96 & \\
\hline \multirow[t]{5}{*}{ Environment } & Informative System & 100 & 4.1 & 0.31 & 0.87 & \multirow[t]{5}{*}{0.72} \\
\hline & Venture Capital & 101 & 3.9 & 0.42 & 0.85 & \\
\hline & Market pull & 101 & 4.1 & 0.25 & 0.69 & \\
\hline & Customer Flexibility & 100 & 3.5 & 0.47 & 0.58 & \\
\hline & Economy Condition & 101 & 4.1 & 0.24 & 0.65 & \\
\hline \multirow[t]{3}{*}{ Commercialization } & Attract new investor & 100 & 3.8 & 0.54 & 0.71 & \multirow[t]{3}{*}{0.86} \\
\hline & Wealth creation & 100 & 4.1 & 0.45 & 0.87 & \\
\hline & Economic development & 100 & 3.8 & 0.63 & 0.92 & \\
\hline
\end{tabular}

Table 3. Standard Coefficient and Significance Values for the five Hypotheses of the Study

\begin{tabular}{|c|l|l|c|c|}
\hline Hypotheses & \multicolumn{2}{|c|}{ Path } & Standard coefficient & Path significance \\
\hline $\mathrm{H}_{1}$ & Research Oriented & Commercialization & 0.37 & 4.53 \\
$\mathrm{H}_{2}$ & Industry-Oriented & Commercialization & 0.44 & 4.87 \\
$\mathrm{H}_{3}$ & Technology Parks & Commercialization & 0.19 & 3.12 \\
$\mathrm{H}_{4}$ & Government & Commercialization & 0.52 & 5.74 \\
$\mathrm{H}_{5}$ & Environment & Commercialization & 0.14 & 3.84 \\
\hline
\end{tabular}


Model goodness of fit

$x^{2}=874.6, \mathrm{df}=369$

$x^{2} / d f=2.4, \mathrm{NFl}=.89, \mathrm{CFl}=.91, \mathrm{SRMR}=.06$
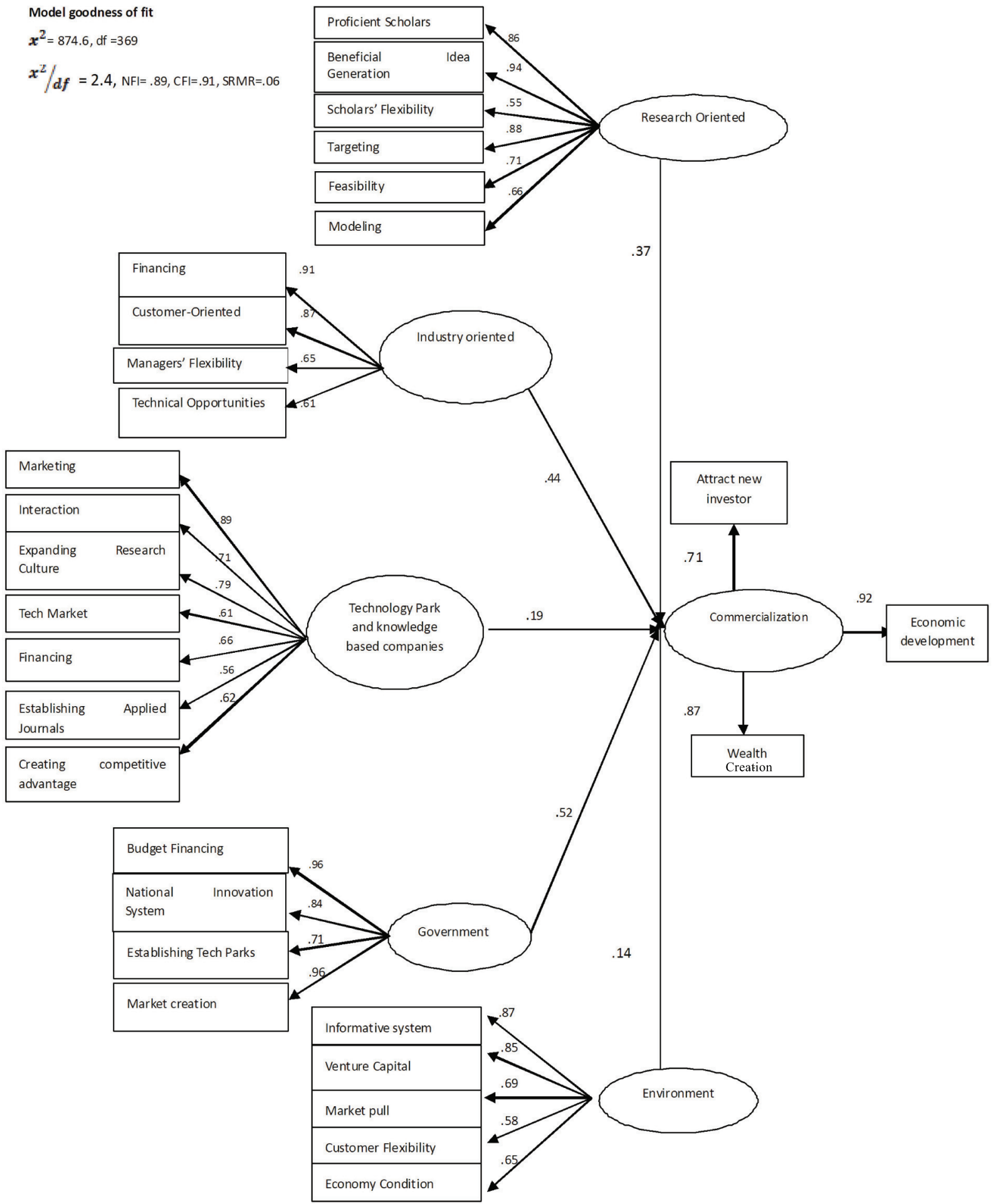

Figure 1. Structural Equation Model of Commercialization 


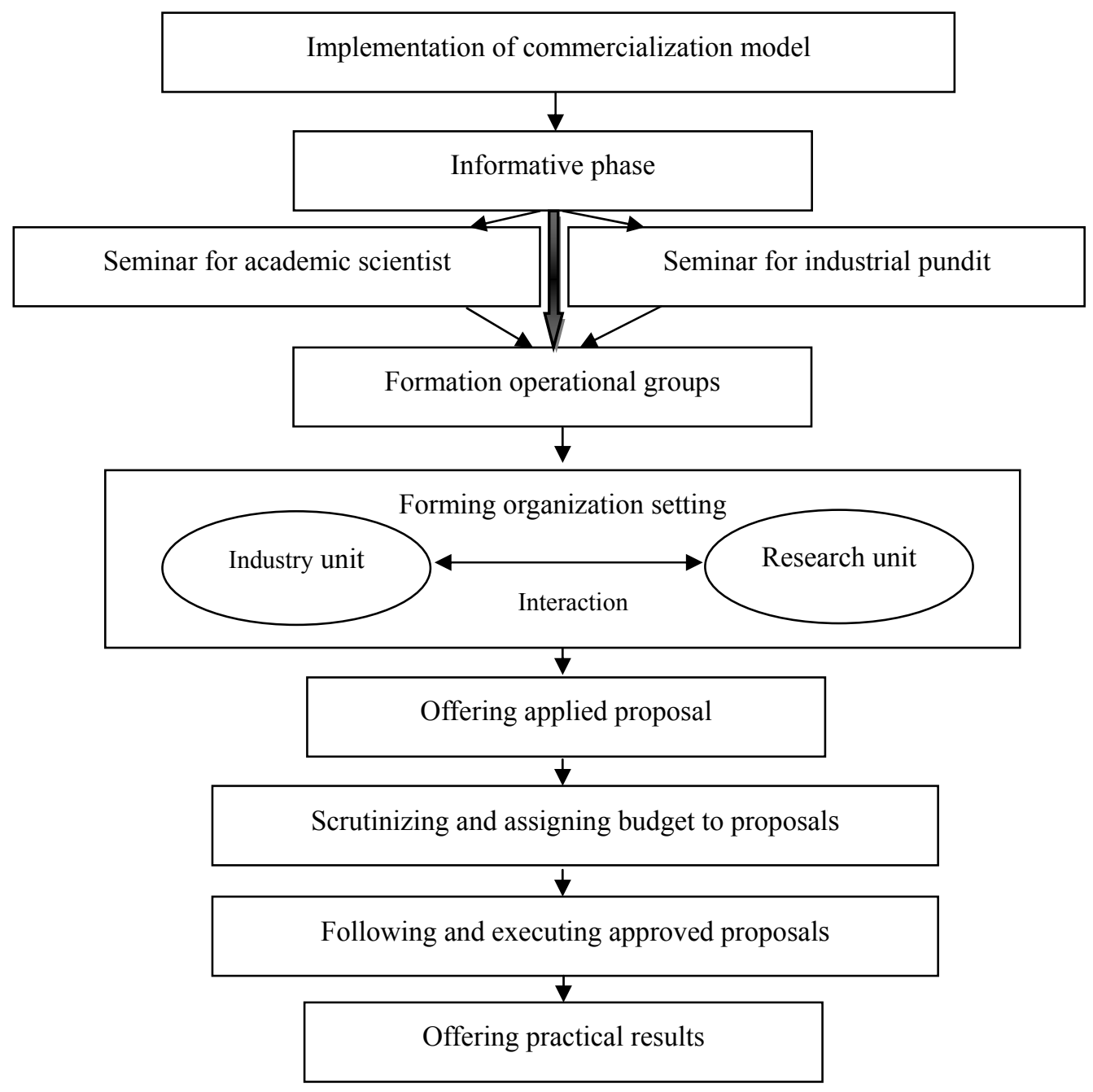

Figure 2. Methodology of Commercializing Research Outcomes 